\title{
РЕАЛІЗАЦІЯ МІЖДИСЦИПЛІНАРНИХ ЗВ'ЯЗКІВ ЗАСОБАМИ ОНЛАЙН ОЛІМПАДИ «ПРОГРАМУВАННЯ ТА АНГЛІЙСЬКА МОВА ЗА ПРОФЕСІЙНИМ СПРЯМУВАННЯМ»
}

\author{
(C) Стяглик H.I., 2019 \\ https://orcid.org/0000-0002-0573-3508 \\ http://doi.org/10.34142/2312-2471.2019.62.18
}

У роботі представлено досвід з організащії та проведення он-лайн олімпіади з програмування та англійськоӥ мови за професійним спрямуванням серед студентів напряму підготовки 121 "Інженерія програмного забезпечення», галузі знань 12 «Інформачійні технологї̈» закладів фахової передвищуої освіти. Метою проведеної роботи було розглянути можливі шляхи підвищення навчальної мотивачії та якості навчання студентів в прочесі застосування інтегрованого (дуального) навчання. Саме дуальне навчання сприяє реалізації компетентісного підходу до здійснення освітнього процесу, забезпечуючи розвиток предметних, соціальних та комунікаційних компетентностей. Викладачами профільних дисциплін протягом кількох років здійснюеться робота з підготовки та впровадження в навчальний процес різноманітних форм поєднання викладання англійської мови за професійним спрямуванням та мов програмування, щзо є нерозривним принцииом підготовки висококваліфікованих фахівців галузі знань «Інформаційні технологї̈», зокрема, фахівців з розробки програмного забезпечення. У статті описано основні етапи організації та проведення олімпіади. Розглядаються варіанти організації змагань з використанням різних технологій, засобів та webоріснтованих навчальних середовищ. У роботі надаються рекомендації щзодо організації та проведення змагань з урахуванням того факту, щзо проведення фахових олімпіад надає змогу підвести підсумки роботи з викладання фахових дисцииліни. Залучення студентів до участі у змаганнях різного рівня сприяє виконанню мети і головного завдання навчального закладу і кожного викладача - підвищення якості підготовки кваліфікованих фахівиів. Підготовку студентів до фахових олімпіад бажано здійснювати, спираючись на досвід студента та використовуючи міжпредметні зв'язки з дисциплінами природничо-математичного цүиклу, щзо надає змогу студентам отримати не тільки глибокі теоретичні знання, але й практичний досвід, щуо загалом сприяє самоствердженню студентів та підвищенню науково-практичного потенціалу студентства.

Ключові слова: олімпіада, професійна підготовка студентів, інформаційні технологї, програмування, навчальний прочес. 
Stiahlyk N.I. Implementation of Interdisciplinary Correlations by Means of an On-Line Contest "Programming and English for IT Students"

The paper presents the experience of organizing and holding the online contest in Programming and English for IT students of the specialty 121 "Software Engineering", the specialization 12 "Information Technologies", in colleges of the III levels of accreditation. The purpose of the paper is to show the possible ways to increase the educational motivation and quality in the process of applying integrated (dual) training. For several years teachers of specialized disciplines have been working on the implementation and introduction into the educational process the various forms of the combination of English for IT students and Programming Languages, the indissoluble principles of training of highly skilled specialists in the specialization "Information Technologies". The article describes the main stages of the organizing and holding a contest. The recommendations are provided by holding a professional contest that gives an opportunity to summarize the work of specialized discipline teaching. Involving students to participate in competitions of different levels contributes to the goal achievement and the main tasks of colleges and each teacher, it improves the quality of training qualified professionals. It is desirable to prepare students for professional contests based on students' experience and usage interdisciplinary connections with natural and mathematical disciplines, which enables students to get not only profound theoretical knowledge, but also the practical experience, it contributes generally to students' self-affirmation and the improvement of scientific and practical potential of a student.

Key words: content, students' professional preparation, information technologies, programming, educational process.

Постановка проблеми. Стрімкий розвиток інформаційних технологій та їх впровадження у всі сфери життєдіяльності людини здійснює вагомий вплив на суспільство в цілому, i, зокрема, на систему освіти, завданням якої $\epsilon$ підготовка кваліфікованого фахівця, конкурентоспроможного на сучасному ринку праці. Сучасні тенденції ринку праці до підготовки фахівця з розробки програмного забезпечення містять вимоги не лише стосовно професійного знання мов програмування та навичок вільного володіння інформаційнокомунікаційними технологіями в професійній діяльності, а ще й вимоги щодо мовної комунікації, адже вільне володіння іноземною мовою стає невід'ємним супроводом роботи програміста.

Підтвердження знаходимо у професійних стандартах для IT-фахівців, де невід'ємними складовими професійної компетентності фахівців цієї галузі названо: особистісну компетентність, тобто розвиток індивідуальних здібностей, обізнаність у власних сильних та слабких сторонах, здатність до самоаналізу, динамічні знання; соціальну компетентність - здатність спілкуватись та брати відповідальність, вміння організовувати співробітництво, проявляти ініціативу та активну участь у соціальному житті суспільства. 
До цього ж відносять методологічну компетентність, яка означає гнучкість, самоспрямоване навчання, здатність до незалежного вирішення проблем, самовизначення та $є$ вимогою для розвитку предметної компетентності, яка передбачає розуміння місця кожної науки у системі знань людства, діалектики отримання нових теоретичних знань та їх використання на практиці, незалежне оперування предметними знаннями та їх критичне осмислення 3 позицій практики та інших наук; та комунікативну компетентність, - здатність особистості застосовувати у конкретному спілкуванні знання мови, способи взаємодії з навколишніми й віддаленими людьми та подіями, навички роботи у групі, володіння різними соціальними ролями [3].

Оскільки мова пройде про вищу освіту, слід зауважити, що освітній процес охоплює студентів вже певною мірою мотивованих до отримання обраної спеціалізації, маючих загальну шкільну підготовку і націлених на здобуття саме професії програміста. Проте кожен заклад освіти, кожен викладач стикається 3 проблемою наявності в одній студентські групі особистостей з радикально різним рівнем базової освіти, різними цілями, здібностями, працездатністю. Виникає потреба реалізації диференціації навчання, особистісної його орієнтації. Здійснення диференційованого підходу до освітнього процесу грунтується на виборі відповідних форм, методів та засобів навчання. Так, однією 3 форм організації навчання та мотивації студентів 3 високим рівнем навчальних досягнень до самовдосконалення та професійного становлення $\epsilon$ навчальні змагання та предметні олімпіади.

Аналіз досліджень і публікацій. Основні проблеми розвитку та навчання інтелектуально обдарованої молоді розглянуто в роботах багатьох науковців, педагогів, психологів (Б. Блум, Д. Богоявленська, Дж. Гілфорд, 3. Калмикова, В. Крутецький, О. Матюшкін, Дж. Рензуллі, М. Смульсон, Б. Тєплов, М. Холодна, I. Якиманська та ін.). Питання організації учнівських олімпіад та підготовки обдарованої молоді до цих змагань розглядали в своїх працях В. Бондаренко, Т. Вакалюк, І. Волков, А. Гуржій, С. Жуковський, М. Кузічев, А. Ляпунов, В. Матюхін, В. Мельник, Н. Павлова, А. Хуторський та ін.

Беручи до уваги високий інтелектуальний потенціал обдарованої молоді і прагнення реалізуватися в якості фахівця з обраної спеціальності, не можна оминути питання використання інтегрованого навчання, яке є базою системної та структурованої підготовки спеціаліста. Аналіз літератури свідчить, що досліджено лише деякі аспекти інтегрованого підходу до навчання студентів. Інтеграційні процеси в освіті розглянуто у працях О. Сергєєва, С. Гончаренко, Ю. Мальованого. Інтеграції природничо-наукових знань присвячені роботи В. Разумовського, Н. Буринської, О. Ярошенко; внутрішньо-предметна інтеграція розглядається М. Гадецьким та ін..

Не можна оминути й питання методики застосування інформаційнокомунікаційних технологій у навчально-виховному процесі, чим займались О. Андрєєв, В. Биков, Л. Долінер, М. Жалдак, К. Комаров, Т. Сєргеєва, В. Солдаткін, О. Спірін, Ф. Хаматнуров, В. Шолохович та ін. 
Виділення невирішених раніше частин загальної проблеми. Як свідчить огляд науково-методичної літератури, питання навчання обдарованої молоді найчастіше розглядається 3 боку певної дисципліни, наповнення іiі змістом, методики іiї викладання тощо. I хоча видатні педагоги наголошують на важливості формування міждисциплінарних зв'язків для розвитку всебічно обізнаної особистості, це питання лишається недостатньо опрацьованим. Окремої уваги заслуговує процес формування міждисциплінарних зв'язків в освітньому процесі фахової підготовки фахівців галузі інформаційних технологій.

Метою статті $\epsilon$ висвітлення особливостей підготовки та проведення інтегрованих фахових заходів (олімпіад, змагань тощо) із поєднанням завдань 3 програмування, інформатики, інформаційних технологій та знанням й використанням англійської мови за професійним спрямуванням.

Виклад основного матеріалу. Підготовка студента у вищому навчальному закладі (ВН3) - процес тривалий, складний, трудомісткий, інтелектуально навантажений. Перед викладачами постає проблема надати не тільки загальне уявлення з предмета, але й зацікавити студента, заохотити його до подальшої самоосвіти, самовдосконалення, мотивувати до отримання достатньо глибоких знань, набуття професійних компетентностей. Підвищення вимог до випускників закладів вищої освіти спонукає до пошуку альтернативних та оптимальних форм здійснення освітньої діяльності.

Однією з таких форм стає інтегроване (дуальне) навчання. Погоджуємось із твердженням А.Кочубей [1], що інтеграція являє собою процес і результат взаємодії елементів, який супроводжується відновленням, установленням, ускладненням і зміцненням істотних зв'язків між ними на основі достатньої підстави, в результаті чого формується інтегрований об'єкт (система) з якісно новими властивостями, в структурі якого зберігаються індивідуальні властивості вихідних елементів. Тобто, на місце окремого вивчення спеціалізованих дисциплін приходить поєднання значущих навчальних предметів, що дозволяє відпрацьовувати практичні навички роботи майбутнього фахівця.

Погоджуємось 3 думкою С. Сисоєвої, що проведення семінарів, студентських наукових конференцій, студентських олімпіад сприяє як розумінню значимості і важливості дисципліни в цілому, так і підвищенню якості підготовки кваліфікованих спеціалістів [5]. Крім того, стрімкий розвиток інформаційних технологій та їх впровадження у всі сфери життєдіяльності людини здійснює вагомий вплив на суспільство в цілому, i, зокрема, на систему освіти.

Наведемо авторський досвід. В межах навчального процесу Харківського радіотехнічного технікуму було започатковано проведення позааудиторних заходів з поєднанням знань профільних дисциплін із використанням іноземної мови та 3 використанням сучасних технічних засобів. Освітній процес Харківського радіотехнічного технікуму орієнтований на професійну підготовку студентів за технічними спеціальностями, що дає змогу 
орієнтуватися на молодь, яка вільно користується інформаційнокомунікаційними технологіями, володіє певними технічними знаннями. Робота 3 технічно-обізнаною молоддю дозволяє виокремити студентів 3 підвищеною мотивацією до набуття фахової підготовки, високим рівнем навчальних досягнень. Саме такі студенти залучаються до участі у різноманітних фахових олімпіадах, змаганнях, конференціях, семінарах тощо [6].

Відповідно до Положення про Всеукраїнські учнівські олімпіади, турніри, конкурси 3 навчальних предметів, конкурси-захисти науково-дослідницьких робіт, олімпіади зі спеціальних дисциплін та конкурси фахової майстерності основними завданнями такої позанавчальної діяльності $\epsilon$ : виявлення та розвиток обдарованої молоді, надання їм допомоги у виборі напряму подальшого навчання у профільному вищому навчальному закладі; стимулювання творчого самовдосконалення студентської молоді; формування творчого покоління молодих науковців та практиків для різних галузей суспільного життя; підвищення інтересу до поглибленого вивчення навчальних, спеціальних та фахових дисциплін, формування навичок дослідницької роботи; підвищення рівня викладання навчальних, спеціальних та фахових дисциплін, фахової підготовки студентів; формування команд для участі в міжнародних олімпіадах, конкурсах, турнірах тощо [2].

Організація олімпіади може мати кілька варіантів. По-перше, можна скористатися сайтом, розробленим саме для проведення олімпіади. В такому разі кожен учасник має власний логін та пароль для доступу до завдань олімпіади. Завдання розміщуються безпосередньо на сторінці сайту. В такому варіанті організації основна проблема полягає у технічній реалізації питань обробки результатів та обмеження часу виконання. Але результати змагань обробляю автоматично впродовж виконання i на момент завершення вже сформовано результати, з якими може ознайомитись кожен учасник.

Другий варіант реалізації - це використання існуючих web-opiєнтованих середовищ, призначених для роботи з групою учасників. У якості такого середовища може бути використаний додаток Google Classroom. Це середовище не лише робить навчання більш продуктивним, а й дозволяє провести i здійснити оцінювання різноманітних курсів, змагань, турнірів тощо.

Google Classroom дозволяє зручно публікувати та оцінювати завдання, організовувати спільну роботу й ефективну взаємодію всіх учасників процесу. Оскільки Classroom інтегрований 3 іншими інструментами Google, такими як Документи, Диск, Форми, то розміщувані завдання можуть бути доволі різноманітними. Так, тестові завдання зручно оформлювати у вигляді Googleформ. Це і завдання на вибір одної чи декількох правильних відповідей серед запропонованих варіантів; і завдання, в яких треба дати свою відповідь.

Запропоновані студентам завдання мають класичну форму, наприклад: Listening Comprehension Task (прослуховування аудіо файлу), Reading Comprehension Task (читання) з виконанням тестового завдання типу Multiple Choic, або завдання типу Use of English 3 використанням термінолексики та лексики, розповсюдженої в цій професійній галузі. Використання таких завдань 
реалізовано завдяки можливості робити посилання на аудіо- та відео ресурси мережі Internet.

Крім того, середовище Classroom дозволяє розміщувати завдання iз посиланнями на інші додатки підтримки навчального процесу. Наприклад, середовище LearningApps дозволяє урізноманітнити навчальний процес, зокрема й процес змагання, за допомогою інтерактивних модулів (програм, вправ), розроблених у формах Quiz: Matching (поєднання двох частин); Simple Order (знайти вірну послідовність); Wordgame Hangman (відгадати термін по буквам) тощо.

Таким чином, ретельно розроблені та підібрані завдання 3 предметів «Іноземна мова за професійним спрямуванням» (English for IT students) та мова програмування $\mathrm{C}++$ мають зацікавити учасників змагання.

Участь в олімпіаді індивідуальна та передбачає попередню регістрацію. Bсі зареєстровані учасники отримують посилання на Google Classroom. Після приєднання до класу кожен учасник має виконати всі запропоновані завдання в будь якій послідовності. Переможців обирають за кількістю набраних балів та часом, що було витрачено на виконання завдань. Кожне з завдань оцінюється за кількома критеріями: правильність відповіді, повнота, кількість використаних спроб та детальне виконання інструкцій.

Передбачено, що кожен учасник по завершенню олімпіади отримає сертифікат із відображеними в ньому результатами. Організатори олімпіади беруть на себе зобов'язання щодо перевірки завдань впродовж доби після встановленого терміну змагань. Оскільки в середовищі постійно діє процес оновлення інформації про здані роботи, то викладачі в змозі оперативно перевіряти завдання, ставити оцінки i навіть додавати коментарі до тих чи інших робіт учасників, що спряє підвищенню рівня комунікації та зворотного зв'язку.

Ще однією перевагою такої організації заходу є відкритість та доступність використаних завдань для подальшого використання не лише студентами, а й викладачами-тренерами 3 метою обміну педагогічним досвідом та поширення ініціативи проведення поза аудиторних фахових заходів, що сприяє підготовці висококваліфікованих спеціалістів галузі інформаційних технологій.

Позитивним $є$ й те, що клас доступний безкоштовно для навчальних закладів, некомерційних організацій і приватних осіб. У цьому сервісі немає реклами, а матеріали і дані учнів не використовуються в рекламних цілях, що забезпечує доступність і безпеку процесу змагань.

Висновки. Таким чином, можемо дійти висновку, що ретельна робота викладачів щодо організації та проведення змагань фахової направленості має сприяти покращенню мотивації студентів до навчання, підвищенню рівня їх зацікавленості у професійній самореалізації. Проведення олімпіадних змагань дозволяє розширити кругозір студентської молоді, сприяє іiі творчій реалізації, стає запорукою результативності всього освітнього процесу. Вважаємо, що робота в цій сфері має поширюватись та знаходити нові форми вираження. 
Отже, інтеграція навчання - це процес зближення, зв'язку наук, що відбувається поруч 3 процесами диференціації. Інтеграція удосконалює i допомагає подолати недоліки предметної системи, і спрямована на поглиблення взаємозв'язків між предметами. Таким чином, перед педагогікою вищої професійної освіти стоїть проблема формування в процесі навчання, підготовки фахівців відповідного світогляду. Дана проблема може бути успішно вирішена лише на основі формування сучасної природничо-наукової картини світу, побудованої в рамках само організаційної пізнавальної моделі з урахуванням інформаційно-семантичних властивостей матеріальних об'єктів.

Перспективи подальших розвідок у цьому напрямі. У подальшому планується дослідити вплив на формування міжпредметних зв'язків залучення фахівців ІТ-галузі до різноманітних заходів фахового спрямування студентів. Перспективними також $\epsilon$ питання обгрунтування практичної реалізації міждисциплінарного підходу на заняттях галузевої та фахової підготовки студентства.

\section{Jimepamypa}

1. Кочубей А.В. Інтеграція як ефективне методичне явище в процесі підготовки студентів технічного вищого навчального закладу./ А.В.Кочубей // Оновленя змісту, форм та методів навчання і виховання в закладах освіти: Збірник наукових праць. Наукові записки Рівненського державного гуманітарного університету Випуск 9 (52), 2014.

2. Положення про Всеукраїнські учнівські олімпіади, турніри, конкурси 3 навчальних предметів, конкурси-захисти науково-дослідницьких робіт, олімпіади зі спеціальних дисциплін та конкурси фахової майстерності [Електронний ресурс] - Режим доступу: URL: http://zakon0.rada.gov.ua/laws/show/z1318-11.

3. Професійні стандарти для IT-спеціалістів. [Електронний ресурс] Режим доступу: https://mon.gov.ua/ua/osvita/visha-osvita/suchasna-it-osvita-vukrayini/ profesijni-standarti.

4. Максимова В.Н. Межпредметные святи в учебно-воспитательном процессе современной школы : учеб. пособ. по спецкурсу для студентов пед. ин-тов / В.Н. Максимова. - М.: Просвещение, 1987. - С. 42 - 47; С. 52 - 61.

5. Сисоєва С. О. Психологія та педагогіка : підручник для студентів вищих навчальних закладів / С. О. Сисоєва, Т. Б. Поясок. - К. : Міленіум, 2005. $-520 \mathrm{c}$.

6. Стяглик Н.І. Досвід підготовки студентів до участі у фахових студентських олімпіадах 3 інформатики, інформаційних технологій та програмування / Н.І. Стяглик // Психолого-педагогічні проблеми вищої i середньої освіти в умовах сучасних викликів: теорія і практика. Матеріали III міжнародної науково-практичної конференції 10 квітня 2018 року. / ХНПУ імені Г.С.Сковороди. - Х.: «Стиль-Издат», 2018. - С.366-369.

7. Навчальне середовище Google Classroom. https://support.google.com/edu/ classroom 
8. Додаток для підтримки навчального процесу за допомогою інтерактивних модулів LearningApps. Режим доступу: https://learningapps.org/

\section{References}

1. Kochubei A.V. Intehratsiia yak efektyvne metodychne yavyshche v protsesi pidhotovky studentiv tekhnichnoho vyshchoho navchalnoho zakladu./ A.V.Kochubei // Onovlenia zmistu, form ta metodiv navchannia i vykhovannia v zakladakh osvity: Zbirnyk naukovykh prats. Naukovi zapysky Rivnenskoho derzhavnoho humanitarnoho universytetu Vypusk 9 (52), 2014.

2. Polozhennia pro Vseukrainski uchnivski olimpiady, turniry, konkursy z navchalnykh predmetiv, konkursy-zakhysty naukovo-doslidnytskykh robit, olimpiady zi spetsialnykh dystsyplin ta konkursy fakhovoi maisternosti [Elektronnyi resurs] Rezhym dostupu: URL: http://zakon0.rada.gov.ua/laws/show/z1318-11.

3. Profesiini standarty dlia IT-spetsialistiv. [Elektronnyi resurs] - Rezhym dostupu: https://mon.gov.ua/ua/osvita/visha-osvita/suchasna-it-osvita-v-ukrayini/ profesijni-standarti.

4. Maksymova V.N. Mezhpredmetnue sviaty v uchebno-vospytatelnom protsesse sovremennoi shkoly: ucheb. posob. po spetskursu dlia studentov ped. yntov / V.N. Maksymova. - M.: Prosveshchenye, 1987. - S. 42 - 47; S. 52 - 61.

5. Sysoieva S. O. Psykholohiia ta pedahohika : pidruchnyk dlia studentiv vyshchykh navchalnykh zakladiv / S. O. Sysoieva, T. B. Poiasok. - K. : Milenium, 2005. -520 s.

6. Stiahlyk N.I. Dosvid pidhotovky studentiv do uchasti u fakhovykh studentskykh olimpiadakh $\mathrm{z}$ informatyky, informatsiinykh tekhnolohii ta prohramuvannia / N.I. Stiahlyk // Psykholoho-pedahohichni problemy vyshchoi i serednoi osvity v umovakh suchasnykh vyklykiv: teoriia i praktyka. Materialy III mizhnarodnoi naukovo-praktychnoi konferentsii 10 kvitnia 2018 roku. / KhNPU imeni H.S.Skovorody. - Kh.: «Styl-Yzdat», 2018. - S.366-369.

7. Navchalne seredovyshche Google Slassroom. https://support.google.com/edu/ classroom

8. Dodatok dlia pidtrymky navchalnoho protsesu za dopomohoiu interaktyvnykh moduliv LearningApps. Rezhym dostupu: https://learningapps.org/ 